\title{
Diverse community energy futures in Saskatchewan, Canada
}

\author{
Margot Hurlbert ${ }^{1} \oplus \cdot$ Mac Osazuwa-Peters ${ }^{2} \cdot$ Jeremy Rayner $^{3} \cdot$ David Reiner $^{4} \oplus \cdot$ Petr Baranovskiy $^{5}$
}

Received: 19 November 2019 / Accepted: 2 May 2020 / Published online: 25 May 2020

(c) The Author(s) 2020

\begin{abstract}
This research explores peoples' place attachment and context surrounding power production and energy futures. Facilitated, deliberative focus groups were conducted as comparative case studies in three fossil fuel-dependent cities in Saskatchewan Canada: Estevan (situated next to the provincial centers of coal, oil and gas production), Saskatoon (situated more northerly and furthest from coal, oil and gas production) and the capital city of Regina. (situated between the other two communities). This study supports the conclusions: (1) participants believed the focus groups improved their knowledge surrounding power production; (2) although there is strong support for wind and solar power production, there is a gap in implementation; and (3) place-based location impacts perceptions of power production sources. Participants were surveyed before and after focus group meetings to explore the perceptions and preferences of power productions sources. All three communities favored renewables in the order of solar and wind. Estevan, supported carbon capture and sequestration (CCS) to a greater degree and perceived much lower risk surrounding CCS than the other two communities. This may be explained by information gaps in this community. Participants were far less likely to believe a climate crisis is occurring, and while recognizing health concerns surrounding coal, they spent considerably more time discussing the loss of coal and its impact on their economy. Saskatoon, the community furthest from coal oil and gas production, spent considerable time discussing renewables, and when asked about coal, oil and gas identified the need to transition and retrain dependent workers. Although the uranium sector is present in Saskatchewan and in closer proximity to Saskatoon, there was little knowledge or support for new small modular nuclear reactors.
\end{abstract}

Margot Hurlbert

margot.hurlbert@uregina.ca

David Reiner

dmr40@cam.ac.uk

1 Canada Research Chair, Climate Change, Energy

and Sustainability Policy, Johnson Shoyama Graduate

School of Public Policy, University of Regina,

CB332.4-2155 College Ave., Regina, SK S4S 4V5, Canada

2 Johnson Shoyama Graduate School of Public Policy, University of Regina, Regina, Canada

3 Johnson Shoyama Graduate School of Public Policy, University of Saskatchewan, Saskatoon, Canada

4 Energy Policy Research Group, Judge Business School, University of Cambridge, Trumpington Street, Cambridge CB2 1AG, UK

5 Johnson Shoyama Graduate School of Public Policy, University of Saskatoon, Saskatoon, Canada 


\section{Graphic abstract}

Deliberative focus groups exploring power production sources and climate, change knowledge and opinions

Fossil fuel communities support:

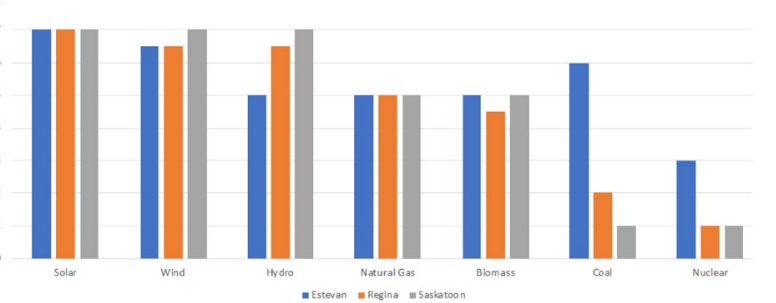

Deliberative focus group participants in three communities in Saskatchewan Canada selected solar, wind and hydro as future power production sources.
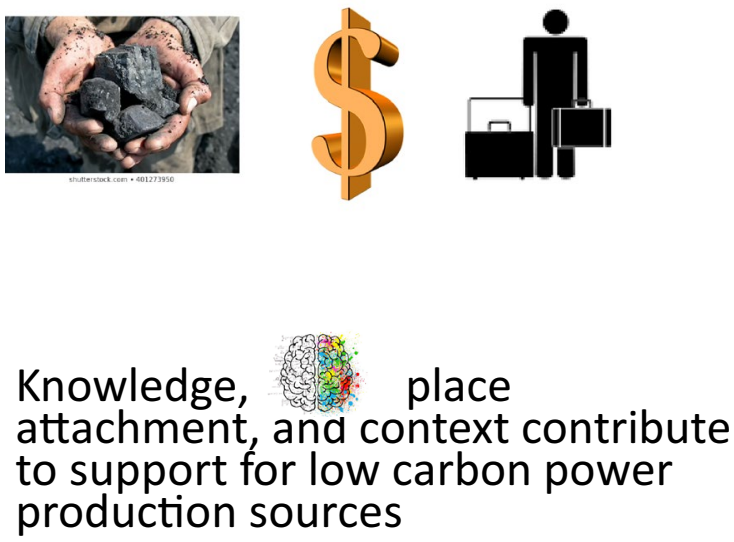

Keywords Energy futures · Clean energy technology · Public opinions · Renewable energy · Carbon capture sequestration · Small modular nuclear reactors

\section{Introduction}

Society plays an active role in accelerating or preventing new decarbonized energy technologies (Pellizzone et al. 2017; Shaw and Corner 2017). There are two gaps: 1. in knowledge surrounding peoples' perceptions of whole system portfolios or future energy scenarios addressing climate change (Pidgeon et al. 2014); 2. in implementation of renewable energy, given the great support expressed by people globally (Wustenhagen et al. 2007). Further, community acceptance research has concentrated on explaining local objections to actual responses not on "upstream" research surrounding the potential for renewable energy projects before they are proposed (Devine-Wright and Wiersma 2020). This research seeks to advance understanding of this "gap" of knowledge and implementation, while also providing a method of deliberative energy discussions to remediate the gap of knowledge by addressing three questions: 1 . Are there benefits of energy futures focus groups or deliberative democracy (Dryzek and Pickering 2017) in increasing knowledge of power production? 2. Is there a gap in the acceptance and implementation of renewable energy power sources (Bell et al. 2013; DevineWright 2011)? 3. How does place attachment inform perceptions and knowledge of power production sources and their implementation (Devine-Wright 2005, 2011)?

The Paris Agreement spelled out an ambitious goal to limit global warming to well below 2 degrees Celsius above pre-industrial levels and to pursue efforts for 1.5 degrees Celsius. The International Energy Agency (IEA) states that "the gap between the goals of the Paris Agreement and efforts on the ground looms large" (IEA 2016: 3) and based on current policies remains off track to 2040 (IEA 2018). The Paris commitments cannot be accomplished with slow incremental change (Vaughan and Lenton 2011), and many climate mitigation scenarios to achieve such a target rely on combinations of new technology including Carbon Capture and Sequestration (CCS) (IEA 2018; Koelbl et al. 2014), renewables and nuclear (Tavoni et al. 2012). While CCS plays a key role in integrated assessment models that build pathways to decarbonization (Bui et al. 2018), nuclear is argued to be essential to achieving zero carbon in a cost-effective manner (MIT 2018). Energy transitions are "wicked" or "messy" problems (Urquiza et al. 2018), as they defy complete definition and final solutions are elusive, as any resolution generates further issues (Rittel and Webber 1973). Saskatchewan, Canada, has historically been dependent on coal (vast deposits of which are situate at its southern border) and developed the first post-combustion CCS plant 
(Osazuwa Peters et al. 2020). The province is currently transitioning to natural gas and renewables and has announced interest in small modular nuclear reactors (SMRs) (Djuric 2019). (Building a large nuclear reactor was considered and rejected by Saskatchewan in 2009 (Hurlbert 2014).) With coal-fired generation facing shut down or expensive CCS modifications, the province offers an interesting case study on people's perceptions of energy futures and power production.

People's narratives and discourses expressed in energy discussions can provide more accurate understandings of people's cultures, lifestyles and decisions (Pellizzone et al. 2019; Allansdottir et al. 2019; Moezzi et al. 2017; Sovacool et al. 2015). Social science can gain input and important insights from communities surrounding energy futures including hopes, concerns, needs, expectations, perplexities, resistance, knowledge and experience (Pellizzone et al. 2017). Comparative case studies can provide evidence of social context and complex social processes, preferences and interests shaping energy systems and their transitions (Sovacool 2014; Geels 2010). The advantage of comparative case studies over other methods (such as a provincial survey of attitudes or individual interviews) is the opportunity to explore context and use multiple methods to gather data (Kaarbo and Beasley 1999). However, Sovacool et al. (2015) conclude (based on a review of thousands of articles in leading energy journals over a 15 year time frame) that qualitative, social science research methods have been underutilized and perhaps under-appreciated in addressing and conceptualizing contemporary energy problems. This research seeks to advance understanding of energy futures in relation to this gap of social science research.

A burgeoning literature explores determinants of the gap in implementing renewable energy projects either at the socio-political (institutional, regulatory, policy) or individual level (people who support renewables in principle, but not their development in their local community) (Bell et al. 2013). ${ }^{1}$ Characterizing this gap in implementation as a "not in my backyard (NIMBY))" opinion is over-simplistic and not supported by social science evidence (Bell et al. 2013). The literature has evolved beyond this mischaracterization to study individual and social gaps in opinion and political outcomes. One explanation is democratic deficits whereby a minority of unqualified opponents prevent implementation (Bell et al. 2013). Explanatory factors might also include tension with land use (Walker 1995), impacts on landscape including equity considerations (Bothello et al. 2017) or people's perceptions inconsistent with their sense of place

\footnotetext{
1 There is no evidence to support the "not in my back yard (NIMBY)" explanation for this gap in implementation (Bell et al. 2013) and literature has evolved beyond this explanation.
}

attachment (Devine-Wright 2011). Place theory explores peoples' place-based symbolic meanings and place attachments (positively experienced bonds or group identity that develop over time in relation to place) and the interaction with new or renewable power production technology (Devine-Wright 2005, 2011).

Increasingly, addressing the gap in implementation involves people in decision making surrounding science with society whereby mechanisms of reflection, anticipation, inclusive deliberation in and around processes of research and innovation are employed (Owen et al. 2012). Decision making processes surrounding new renewable energy technologies require sustained and diffuse efforts from all stakeholders and need to overcome a series of technical, economic, cultural and political barriers posed by mainly fossil fuel locked in energy systems (Pellizzone et al. 2017; Lehmann et al. 2012). Dialogues of interested parties can facilitate experimentation, learning and change (Dietz et al. 2003) whereby people become co-creators of innovation (Pellizzone et al. 2019). Local community solutions are naturally context specific, as achieving them promotes relationships built on reciprocity, self-reliance and accountability (Tokar 2015). The transition path is not linear, well defined or certain.

This research assesses whether there are benefits of energy future focus groups; it explores what people associate with in their discourses, their responses and preferences regarding different energy generation facilities, and how this relates with each community's situated knowledge and context. From this, insights are generated into the implementation gap of renewables and acceptance of other power sources.

The method of engaging with each community using deliberate democracy is important. The question of how to mitigate and adapt to climate change cannot be answered by science alone, as organizing policy response is difficult without a shared understanding of the messy problem of climate change (Shaw and Corner 2017). New thinking about problem definitions and new forms of knowledge are being created through public participation. Participation has emerged both theoretically [through initiatives of energy democracy (Delina and Janetos 2018)] and methodologically through practices of reflexivity and two-way information flows (Urcan and Dryzek 2015; Urquiza et al. 2018). Reflexivity is "the ability of a structure, process or set of ideas to reconfigure itself in response to reflection on its performance" (Dryzek and Pickering 2017: 353). Cognitively, reflexivity occurs through deliberation or a dialogue among people aimed at producing reasonable and well-informed opinions through discussion, exploration of new information and claims made by fellow participants. Participants must be willing to revise their preferences in light of discussion (Chambers 2003). It is recognized that 
these processes cannot be wholly dominated by citizens nor dominated by experts in order to open up, rather than close down conversation surrounding science. Dialogue also cannot be one hundred percent consensual, but must contain contested elements for re-evaluation and reflection (Dryzek and Pickering 2017). Because of these considerations, the focus groups were orchestrated as described in the Methods.

\section{Methods}

This is a comparative case study of energy pathways deliberated in three urban cities in Saskatchewan in 2017. The approach taken here is similar to that adopted in Ostfeld and Reiner (2020) for the case of Scotland, another energy-rich jurisdiction. Case studies are appropriate for exploring social phenomenon (Yin 2014) and provide analytical boundedness for comparison (Elger 2010). Focus groups were conducted in Estevan (8 people), Regina (10 people) and Saskatoon (10 people) over $3.5 \mathrm{~h}$. These centers were chosen as they reflect the larger urban centers in the province geographically spread over the populated area of the province from south to north, with Estevan closest to coal power production (Estevan 2018) and then Regina (Regina 2018) followed by Saskatoon (Saskatoon 2018) the furthest away; no one community is close to large wind or hydro power installations. Figure 1 is a map of these locations in Saskatchewan, Canada, and power production sources.

Participants were selected through random cold calling and screened in order to represent the gender, age, education and income demographics of each community (as depicted in "Appendix 1"). As depicted in "Appendix 1," Saskatchewan community demographics are relatively similar. Not surprisingly Estevan, surrounded by a coal, oil and gas economy, is characterized by a slightly lower educational attainment, but a slightly higher income distribution.

Structured focus groups moderated by an experienced facilitator ensured the same questions and activities occurred in each location, and all participants were heard from (with no one person dominating discussions). Upon arrival, participants were surveyed (see instrument in Appendix II). In the survey, participants ranked preferences in relation to sources of power production, concerns relating to climate change and the environment, knowledge of CCS and nuclear. Next, after brief introductions, a review of ethic consent forms and the agenda, participants were asked to choose words, phrases, thoughts or images associated with energy production in Saskatchewan and then feelings about the future of oil and gas production in Saskatchewan and its impacts on the local economy. Participants were then asked if they had heard of CCS (and what they heard and knew about it) and if they had heard about SMRs (and what they heard and knew about it). The expert then entered the room and presented an introduction to Saskatchewan power production including sources of generation and key challenges (including reducing emissions by $40 \%$ by 2030 and doubling the percentage of renewable power by 2030).

In this research, there was explicit recognition that the method of citizen engagement can create inherent bias and predisposition in outcome (Mann et al. 2014). Therefore, in order to encourage reflexive citizen engagement, avoid techno-scientific closure (Vob and Amelung 2016) and counter the inherent tension and significant influence between scientific and citizen actors on debates, agendas and decisions (Blue and Medlock 2014: 565), after presentation the expert left the room. Participants reflected on the expert's presentation and formulated questions for the expert. The expert then re-entered the room and answered the questions through a facilitated group discussion. Thereafter, the expert gave a second presentation reviewing SaskPower's supply mix commitments and discussed CCS, wind, solar, natural gas, SMRs, energy efficiency and conservation. The expert again left the room for questions to be formulated returning later for discussion. At the end of the focus group, participants completed the same survey in Appendix II.

Answers to the survey were analyzed using SPSS. The Fisher's exact test was used to test for differences between communities in categorical dichotomous (yes/no or true/ false) data. Discussions of the focus groups were taped, recorded and analyzed. The taped discussion of the focus groups was transcribed and coded using a coding guide to draw out major themes. These data are not statistically significant nor representative, due to the low number of focus group participants.

\section{Results and discussion}

The results of the comparative case study are discussed in relation to the three questions:

1. Are there benefits of energy futures focus groups or deliberative democracy (Dryzek and Pickering 2017) in increasing knowledge of power production?

The method employed in the focus group arguably opened up conversation and increased reflexivity. When surveyed in relation to the experience, participants rated the experts that presented as knowledgeable, honest and without bias. They also found that the information presented was clear. The process also advanced reflexivity as participants showed a willingness to revise their opinions, an important factor in advancing reflexivity (Chambers 2003).

Participants acknowledged that their views did change in relation to CCS. Regina and Estevan's median answers were that participants became slightly more positive about 


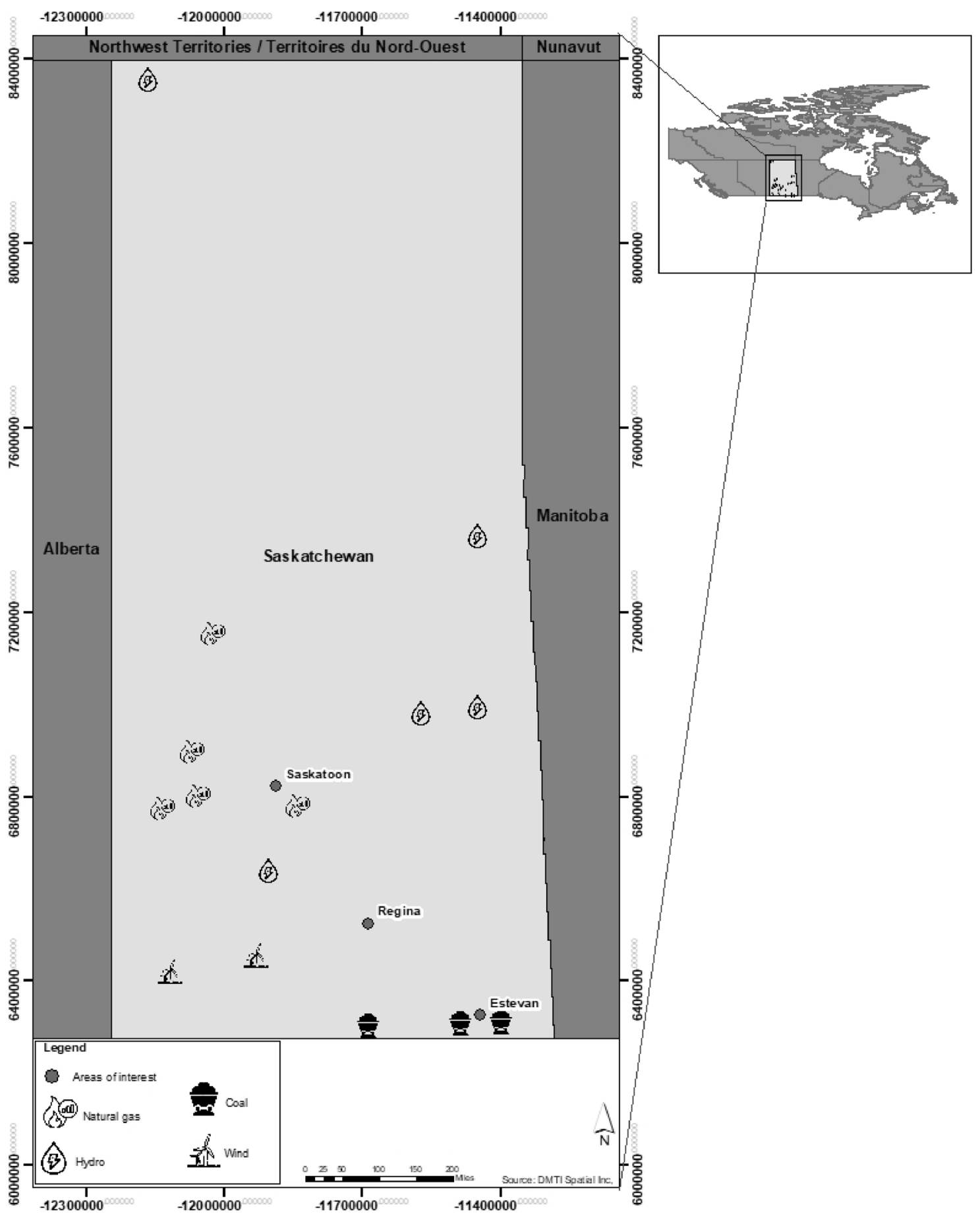

Fig. 1 Map of Saskatchewan, Canada, and location of focus groups

CCS, while Saskatoon's views changed the most answering "I became much more positive about CCS." After the second expert, energy presentation participants identified many things they learned about CCS. Several were impressed that $90 \%$ of $\mathrm{CO} 2$ was captured, thought it innovative, a good idea and forward thinking. A few comments still noted that "storing carbon underground is just riding the culprit. What are the long term effects on the environment?"

There were no statistically significant changes in survey results of participants pre- and post-focus group. However, statements made by participants evidenced learning and change in opinions. At the end of the focus group discussion, 


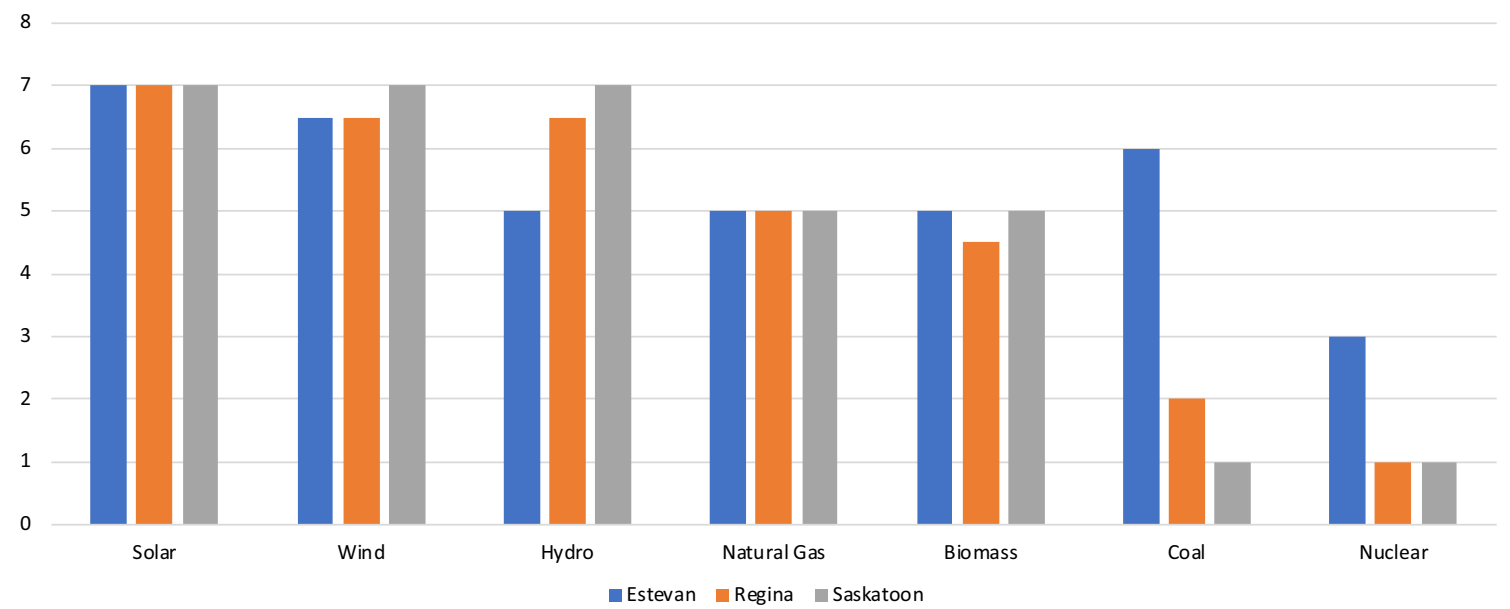

Fig. 2 Ranking of Sources of Power Production by Community Case Study

Estevan participants identified that there were changing views on the current energy situation in Saskatchewan and that they were more comfortable with CCS, open to other options, and a few made favorable comments in relation to SMRs describing them as "relatively safe." Some statements were slightly inconsistent: one stated that views were, "Not changed - more open to SMR use"; another stated, "learned a lot - opinion not changed." Generally participants felt more knowledgeable but were interested in knowing and learning more.

2. Is there a gap in the acceptance and implementation of renewable energy power sources?

The Saskatchewan case study is one study suggesting a gap. High levels of support for renewables (solar, wind and hydro) exist, but diminutive implementation contradicts this support (Devine-Wright and Howes 2010; Devine-Wright 2011; Bell et al. 2005, 2013; Wustenhagen et al. 2007). For each power production source appearing in Fig. 2, participants expressed on a Likert scale from one to seven the extent they opposed (ranking of 1) or favored (ranking of 7) each individual source. Sources were those where there was some inconsistency between communities related to hydro and coal (discussed below in relation to place-based differences). This ranking is similar to the ranking of negative externalities associated with these energy systems from lowest to highest (cents/kWh) which is: solar, wind, hydro, gas, biomass, nuclear and coal (Sundqvist 2004).

All three communities ranked wind and solar as the most preferred sources of power production. Wind and solar installations are not situated in close proximity to any of these communities. Saskatoon, the city located furthest from the coal oil and gas industry in the south side of the province, discussed renewable energy, the environment and concern over climate change for a longer duration than the other two focus groups. Regina's discussion focused on thinking outside the box, concern for future generations, increasing support for solar and storing energy from renewable resources. Saskatoon participants expressed more optimism stating they were "hopeful" and "encouraged by the percentages of renewables by $2030 . "$

A gap exists between the level of support that exists for different power production sources and the proportion deployed in the Saskatchewan context (Devine-Wright and Howes 2010; Devine-Wright 2011; Bell et al. 2005, 2013; Wustenhagen et al. 2007). Figure 3 depicts sources of power production in Saskatchewan in 2018 whereby coal and natural gas are deployed in greater proportions than the proportionate level of preference depicted in Fig. 2. Natural gas received only marginal support at a " 5 " on the scale from a ranking of 1 (opposed) to 7 (strongly support). Thus, Saskatchewan as a case study illustrates a gap in knowledge

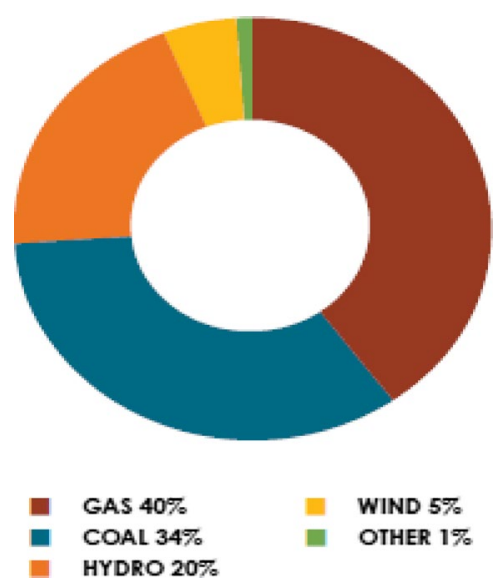

Fig. 3 Current capacity of SaskPower by generation source 
and implementation of renewables discussed in Introduction. Saskatchewan currently has a plan that by 2030 , it will have $50 \%$ renewable energy capacity by generating power from solar, wind and possibly geothermal, but only $25 \%$ capacity currently exists (Boyd 2015; SaskPower 2019).

3. How does place attachment inform perceptions and knowledge of power production sources and their implementation?

The place attachment and related symbolic meanings of sources of power production in Saskatchewan are contextual (Devine-Wright 2011). Consistent with Wustenhagen et al. (2007) dimensions of social acceptance are illustrated in Saskatchewan and its community context. The Saskatchewan socio-political context was presented and confirmed by an expert presentation on the provincial power production sources and futures (specific to SaskPower plans relating to CCS, SMRs, etc., in Saskatchewan). Large solar projects do not yet exist in Saskatchewan, but only rooftop installations exit. Participants envisioned solar project as individual home owner deployed solar project. Large wind projects dominate the major highway in rural remote locations linking Saskatchewan to its bordering provincial neighbors, while single or small wind projects, owned by independent power producers (not the provincial electric utility) and located close to urban centers, are relatively rare. Discussions in focus groups were favorable to wind and solar, but did not deviate from this current vision of wind and solar infrastructure. As hydroelectric potential does not exist in Saskatchewan and the expert presentation confirmed this, it was not discussed in the focus groups in any great detail. ${ }^{2}$

\section{(a) Place attachment and coal, oil and gas}

The focus groups provide information on Wustenhagen et al.'s third dimension of "community acceptance," which differed in each community. Estevan's rankings of power production sources deviated from Regina and Saskatoon's. Although Estevan did rank solar and wind as the two most preferred sources of power production, participants' third choice was coal followed by hydro, natural gas, biomass, and then, nuclear. This ranking evidenced a place attachment (Devine-Wright 2011) of Estevan participants to their coal, oil and gas community and its infrastructure.

Consistent with findings of Bothello et al. (2017), this is in part explained by equity considerations focused on who

\footnotetext{
${ }^{2}$ Wustenhagen et al.'s second dimension of "market acceptance" of renewable sources cannot be determined as Saskatchewan accords SaskPower a virtual monopoly position in relation to power production and supply in the province (The Power Corporation Act, R.S.S. 1978, c. P-25).
}

benefits from which power production sources and who suffers. Discussions in Estevan were predominantly around the economy and jobs. There was particular concern over the loss of coal mining and coal power production and the impact on the community. Estevan also held significantly different thought in relation to CCS (that is associated with coal power production) than the other two communities. CCS was discussed specifically in relation to extending the economy around oil and coal.

Perceptions of CCS risks were one of three results analyzed in the survey that confirmed significant differences between the communities. ${ }^{3}$ When asked about drawbacks in relation to CCS, Estevan residents believed there were no risks associated with CCS at a rate 20.83 times higher than Saskatoon. Many in Estevan expressed pride in being host to the first commercial scale CCS plant and viewed the investment in the technology as better than a carbon tax. Conversely, In Regina, participants were concerned that focusing on CCS distracts from development of renewable energy sources. In Regina, one participant mentioned the amount of money used to get CCS up and running and the fact it was not capturing much $\mathrm{CO} 2$; another mentioned it took a long time and was not sure it was operational; and a third referred to the huge investment at the expense of renewables. Saskatoon had six people state they "didn't know" about CCS, and a few others wondered if it was working or not, and if they were being told the truth. No one in Saskatoon, and only two people in Regina, spoke in favor or support of CCS. Estevan's discussion engaged more broadly with advantages of CCS including potentially selling the technology to places like China, receiving a credited carbon abatement in relation to Nationally Determined Contributions, and Saskatchewan being a leader in clean energy technology globally because of the Boundary Dam CCS plant.

Estevan's place attachment to coal, oil and gas may be partly explained by two information gaps: (1) the crisis of climate change and impacts on the environment and (2) the impacts of coal, oil and gas on health. First, Estevan participants generally failed to recognize the crisis of climate change and the environment. When asked to identify which of the following statements best reflected their own view on climate change, more Regina and Saskatoon people identified with the last statement, and more Estevan people identified with the first (as illustrated in Fig. 4:

1. Don't know

2. I'm still not convinced that climate change is happening

\footnotetext{
3 The other two results were: Estevan ranked friends, family and colleagues 16.28 times higher and newspapers 10.45 times higher as sources of information about energy than in Saskatoon. Again, the surveys are not representative samples.
} 


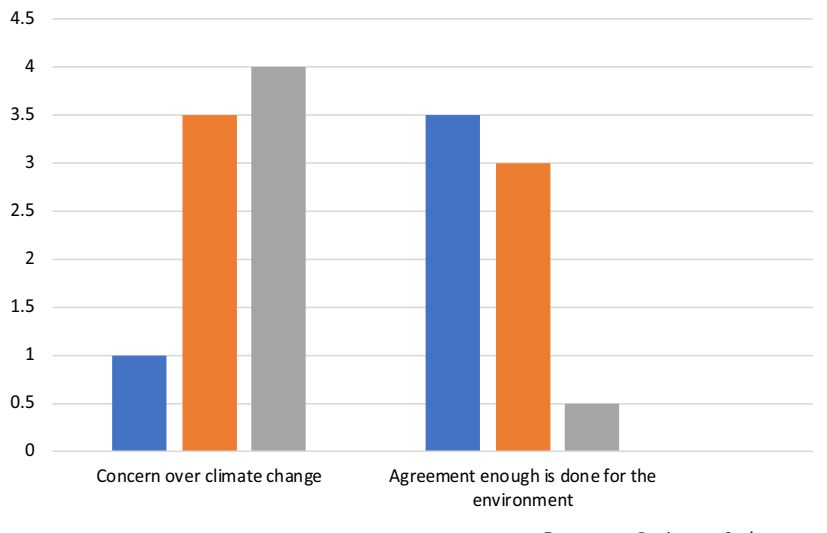

๓Estevan $₫$ Regina $\amalg$ Saskatoon

Fig. 4 Case study views of climate change, environment and fossil economy

3. Climate change is not really a problem

4. Climate change is more of a problem for the future

5. Climate change is an immediate and urgent problem

Figure 4 also illustrates the level of agreement that "enough is being done to protect the environment" in stark contrast to recent Intergovernmental Panel on Climate Change reports (IPCC 2019). These answers were ranked from (1) "Don't know and strongly disagree" to (5) "Strongly agree." More Estevan participants strongly agreed that enough is being done to protect the environment, and far more Saskatoon participants strongly disagreed.

Second, an irreconcilable gap in knowledge emerged in Estevan connecting and reconciling support for coal, oil and gas and simultaneous concern over the industry's impact on health. Only in Estevan did discussion center around health impacts of coal, oil and gas. Initially, when speaking to the future of oil and gas in Saskatchewan one participant identified the unusual amount of people from Estevan and Yorkton with lung problems. During the focus group, the cost of oil in relation to health was noted and described as "a pretty big price we are paying for it in ways that money just doesn't compare." Another participant agreed, "Yes, cancer population here is high, denser. It's easy to figure out because of the particulates in the air. You wash your vehicle, you set it out overnight, you come out in the morning the thing is full of dust." This discussion was inconsistent with the discussion in Estevan of jobs and economy surrounding coal, oil and gas. Regina and Saskatoon did not identify the health concerns of oil and gas. Future research should include questions surrounding health impacts of coal, oil and gas and explore these implications and connections in greater detail, especially in relation to support for the coal, oil and gas economy.

(b) Place attachment, support for renewables and the environment
Saskatoon, the community furthest away from the coal, oil and gas economy was as supportive as Estevan and Regina in the rankings of solar and wind and ranked hydro the highest. However, the quality of the focus group discussions was far more supportive of renewables in time spent and depth of discussion surrounding renewables. In response to the initial question of "what words, phrases, thoughts or images participants associated with energy production in Saskatchewan," Saskatoon participants focused predominantly on renewable energy and the environment. As depicted in Fig. 4, Saskatoon expressed the most concern for the environment and was significantly less in agreement with the idea that "enough is done for the environment." When asked to rank what is most important when it comes to deciding which types of energy are produced in Saskatchewan, in Saskatoon, effects on the environment were the most important consideration for energy choice followed by cost (impact on consumer bills). Conversely, in Regina and Estevan, cost was the most important followed by effects on the environment (including climate change and local air pollution) and then energy independence (not relying on foreign sources).

In Saskatoon roof top solar, net metering and renewables were supported and dominated the conversation. One participant stated, "Why aren't we putting more money into developing a system that works in Saskatchewan for residents to use more solar?" Saskatoon went further that Estevan and Regina and discussed environmental destruction from fossil fuels, moving away from them to solar, biomass, changing lifestyles and caring for the environment. One participant stated, "Clean and Green is how we have to go if we want to keep living here. Period." Many comments related to protecting the environment for future generations. When concern for jobs (in the oil sector) came up, the discussion quickly turned to retraining of people to work in renewable energy, instead of the oil industry. This was regarded as an opportunity for universities, trade schools and people.

The information gap concerning the environment and climate change noted above in Estevan did not exist in Saskatoon. Saskatoon did identify the fortune of Saskatchewan in having natural resources and an abundance to export, but identified the broken relationship with nature as the problem. Participants also noted the need for change, the financial impact of transition, the desire to retrain oil worker to work on wind farms and the need for government to do something. Regina straddled the two other communities mentioning, coal, power, turbines, non-renewables, renewables, windpower, solar, the environment, expense and risks/impacts. When asked the next question about the future of oil and gas production in Saskatchewan, Regina identified the under-valuing of resources through low royalty revenue, the expense, infrastructure, jobs, money, revenue and financial implications of the oil industry. Regina focused on lack of or inadequate knowledge about energy and environmental issues. Although there was passing mention in discussions in Estevan surrounding renewables and support for renewables, Estevan 


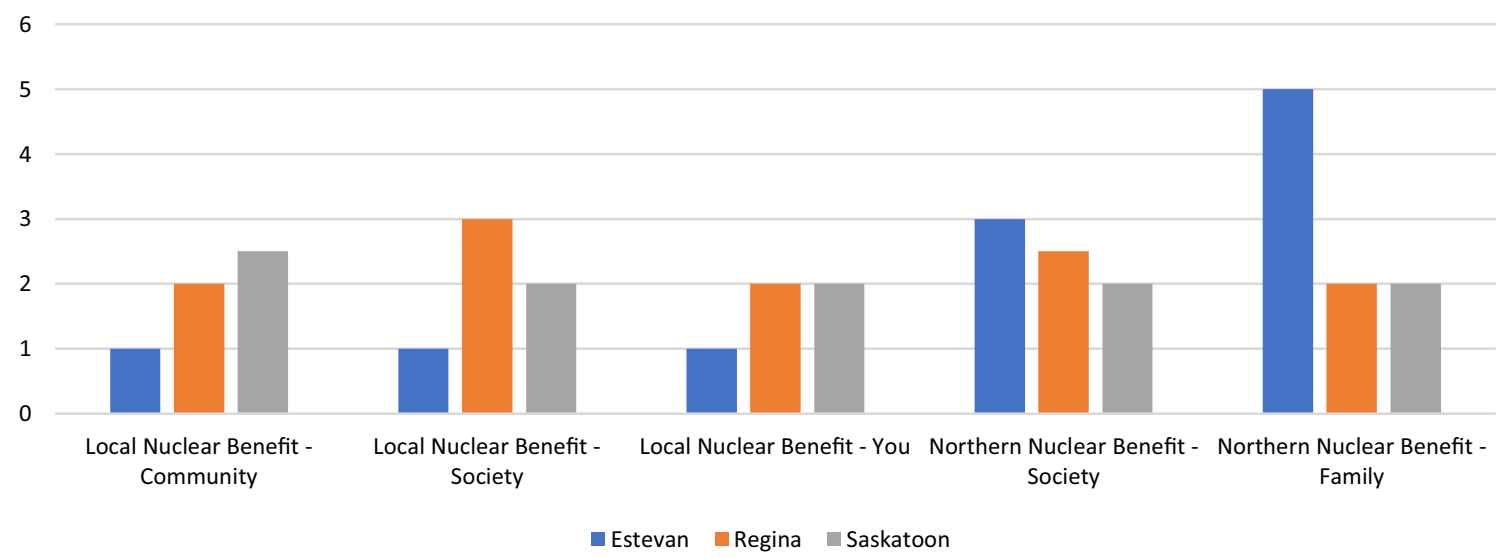

Fig. 5 Perceptions of SMR benefits

discussed economy, oil fields, coal, electricity, natural gas, jobs and cost. Estevan discussed the uncertainty of the industry, jobs, economy and the impending impact of carbon tax.

(c) Information gap and concern over Small Modular Reactors (SMRs)

In relation to uranium mining and nuclear energy, this research found that people do not necessarily accept and support sources of power production that they live in proximity to, and this is partly due to an information gap. Saskatchewan does not have a nuclear power plant. However, Saskatoon has had a nuclear slow poke reactor for decades and is closer to uranium mining in the north and home of the head office in Saskatchewan for Cameco, Saskatchewan's uranium mining company (Saskatoon 2017; Parker 2009). Regardless, there was little support expressed for SMRs in Saskatoon and for nuclear energy in general (as evidenced in Fig. 3 above).

This could be due to the fact there was little knowledge about SMRs, even in Saskatoon. In all three locations, participants were not aware of SMRs. In Saskatoon, the facilitator stated: "(Facilitator) Small modular reactor. Do you know what they are, advantages or disadvantages...(Participant) I actually have no idea what it means. I could probably give you a pretty good educated guess, but... (Facilitator). How about you? .... (Participant)...Am in the same boat..." Prior to expert energy presentations, nine people in Saskatoon and three in Estevan stated they knew nothing about SMRs. In relation to place-based interpretation of a new source of power production, SMRs would appear to be in the first stage of "becoming aware" and not within later stages of interpreting, evaluating, coping and acting (Devine-Wright and Howes 2010). The deliberative dialogue provided initial information on SMRs and pursued questions advancing participants' interpreting and evaluating of the technology.

Participants found little benefit for themselves and their families personally, their community and society whether the
SMR was local or located far away from their community as depicted in Fig. 5. In comparison of positive and negative statements in relation to SMRs, there were 11 negative statements and 6 positive ones. Even though many participants had no previous knowledge about SMRs, many negative associations were made including, "I know nothing about them but when I hear reactors I assume, and it makes me nervous." Another said, "that sounds like atomic energy" and quickly associated it with nuclear development for security and bomb making. One said" Can I use one word? Chernobyl. Small reactors are just small explosions, small meltdowns. Big reactors are big meltdowns." Others associated nuclear plants with cancer referencing high cancer prevalence rates in Ontario where the Bruce plant is located. All locations identified health and safety concerns with SMRs. In Regina, one stated, "What would be the health hazard if something should go wrong?" One Saskatoon participant described SMRs in one word, "BOOM." After the expert energy presentation, when surveyed, participants in all communities continued to oppose SMRs.

However, Estevan ranked nuclear energy in Fig. 2 higher than the other two communities (at 3 in contrast to 1) on a scale indication the level to which participants believed a proposal to develop a nuclear project in Saskatchewan would benefit their community, society, themselves. A ranking of 1 was "very low" to 7 "very high." This question was asked in relation to a local nuclear facility and a "northern" nuclear facility (in the north of Saskatchewan far away from all communities depicted on the map in Fig. 2). Figure 5 also illustrates Estevan's reduced opposition to nuclear. On the last graph of Fig. 5, Estevan valued a northern nuclear plant higher than the other two case study communities. At first, it appears an illustration of "not in my backyard," as local nuclear was far less valued than a northern nuclear plant far away from Estevan.

Estevan's discussions centered on similar events to Chernobyl and Fukishima, however comments in favor of SMRs surrounded economic potential, exploring Saskatchewan's uranium deposits and potential for cheaper energy. One 
comment at the very beginning of the focus group from Estevan when participants were asked for words, phrases, thoughts or images associated with energy production in Saskatchewan was "Wonderful resource in North for nuclear power." It appears that Estevan's support for northern nuclear deployment related to the development of uranium (already mined in the north) and its economy in a similar fashion to the coal, oil and gas economy in Estevan. This is arguably an example of anchoring in social representation theory or classification of a new sociotechnology or object into previous and familiar knowledge (Batel and Devine-Wright 2015). In this way, Estevan emerged as a community of relevance for (distinguishable from a community affected by) nuclear power (Batel 2018). Although several of the negative comments surrounding SMRs also came from Estevan, these comments illustrate that a community dependent on energy resources may be more amendable to continuing the energy economy in relation to other energy sources such as nuclear.

\section{Conclusion}

This research explored place attachment and context in relation to energy futures. Participants believed 3-h deliberative energy dialogues improved their knowledge of power production. Although there was no significant difference in identical surveys completed by participants before and after focus groups, participants felt they had learned information and were better equipped to understand and participate in power production dialogues and decisions in the future.

This research did reveal an implementation gap in expressed support for renewable energy of wind and solar and its implementation in Saskatchewan, similar to findings of Bell et al. (2013) and Devine-Wright and Howes (2010), Devine-Wright (2011). Although participants ranked solar and wind energy as the most desirable sources of power production, they are proportionally small as a percentage of Saskatchewan's power production sources. In this study, this implementation gap is not explained by the "not in my backyard" sentiment as per Bell et al. (2013). It is explained by knowledge gaps, perceptions of risk and value and Saskatchewan's social political context.

The Saskatchewan social-political context makes wind situate predominantly in large installations in rich wind resource areas and solar predominantly comprised of individual rooftop installations (as per Wustenhagen et al. 2007). This social political context is reflected in Saskatchewan's power production infrastructure depicted in Fig. 1 and was common to all three communities. Knowledge gaps, perceptions of risks and values differed by community.

Saskatoon, located furthest from coal, oil and gas production, had the highest support for renewables reflected in the quantitative survey (Fig. 3), and also resoundingly in the qualitative focus group discussions. This community went so far as to discuss transition to renewables, retraining of those employed in the coal, oil and gas industry, and opportunities surrounding the transition to renewables. The community of Saskatoon (Wustenhagen et al. 2007) recognized the climate change crisis and the full costs of pollution from coal, oil and gas.

For Estevan, situated close to the coal, oil and gas industry, participants focused on the loss of coal, oil and gas economy and jobs. Estevan residents also to a statistically significant extent supported CCS and determined it less risky than the other two communities. Two knowledge gaps were found to exist in this community context. Climate change was not viewed as a crisis, and participants expressed concern surrounding the health of community residents because of the coal industry. These voices underscored an incongruent knowledge gap in reconciling health and the climate crisis with the importance and reliance on the coal, oil and gas economy. Issues surrounding equity (Bothello et al. 2017) were paramount in the Estevan context. Participants were concerned with the lack of consultation with the community about the impact of a carbon tax and its procedural and distributive fairness in relation to loss of jobs. For Estevan, deliberation surrounding future power production was viewed predominantly as a loss of status quo, whereas in Saskatoon it was viewed as preserving the Earth and its status quo (Kahneman 2011).

An information and knowledge gap existed in relation to SMRs in all three communities. Most participants had little knowledge of SMRs (which was particularly surprising in Saskatoon situate closest to uranium mining in Saskatchewan's north and a site of a slow poke reactor for many decades). This lack of knowledge is in stark contrast to Estevan participants' deep knowledge of oil, gas, coal and CCS; arguably this state of affairs raises many questions. This study documented a lack of knowledge in Estevan surrounding climate change, but knowledge of CCS; although Saskatoon had knowledge of climate change, there was a lack of knowledge surrounding SMRs and CCS, both of which are technologies identified as necessary for meeting commitments made in the Paris agreement (IEA 2018; MIT 2018). More research, especially social science research, exploring these knowledge gaps is required (Sovacool 2014).

Citizen engaged dialogues achieved Devine-Wright and Howes (2010) stage of having participants "become aware" of the technology and allowed for some interpretation and evaluation by participants. Estevan had less opposition to SMRs, even favoring more than other communities the development of an SMR in Saskatchewan's north. This was not evidence of "not in my backyard" ((confirming Bell et al. (2013)) because of Estevan's dialogue pertaining to economy, jobs and leveraging the north's already-existing uranium mining. Estevan's place attachment with an energy economy anchored their support as a community of relevance supporting nuclear power and SMRs in the north (Batel and Devine-Wright 2015, 2018). 
Participants were supportive of having group deliberations balanced with expert presentations in the focus groups. This procedure provided opportunities for participants to discuss expert presentations and formulate questions without the expert present. Because of this method, participants assessed the experts as very knowledgeable, providing clear information, and not being biased. This method also advanced reflexivity of Dryzek and Pickering (2017) or a willingness of participants to reflect on and revise their opinions as participants did report that they had learned about energy sources and their views on CCS as well as other matters changed. Because of the diverging views expressed in Estevan surrounding loss of economy and jobs versus Saskatoon surrounding preservation of the earth and addressing climate change, it may be that deliberative engagement may enhance reflexivity if it occurs in a regional or intercommunity basis. A gap in knowledge exists within the research community in understanding community dynamics and methods of deliberative engagement optimizing reflexivity.

Future research comparing these Saskatchewan case study communities to other communities in Canada would allow for comparison to communities that have and rely on nuclear power or where hydroelectric development is still available and potentially at Uranium City where uranium is mined. Bridging place-based attachment between communities may advance reflexivity. Inter-community dialogues might advance contestation and dialogue of participants, especially if Estevan's coal, oil and gas community were mixed with Saskatoon's renewable energy and climate change concerned community. However, this is a gap in knowledge about how to foster the deliberative dialogue bringing together values such as those in Estevan, together with those in Saskatoon, in order to address the wicked problem of climate change. Differing methods exploring trust, emotions and values around different power production technologies in different community contexts would expand upon and delve further into this paper's exploration of narratives, reflexivity and place attachment.

Acknowledgements Funding is gratefully acknowledged from the Sylvia Fedoruk Canadian Centre for Nuclear Innovation, University of Saskatchewan, Canada. DMR was funded by the International Research Collaboration Fund of the UK Carbon Capture and Storage Research Centre, supported by UK Engineering and Physical Sciences Research Council (EPSRC) grant EP/ K000446/2.

Open Access This article is licensed under a Creative Commons Attribution 4.0 International License, which permits use, sharing, adaptation, distribution and reproduction in any medium or format, as long as you give appropriate credit to the original author(s) and the source, provide a link to the Creative Commons licence, and indicate if changes were made. The images or other third party material in this article are included in the article's Creative Commons licence, unless indicated otherwise in a credit line to the material. If material is not included in the article's Creative Commons licence and your intended use is not permitted by statutory regulation or exceeds the permitted use, you will need to obtain permission directly from the copyright holder. To view a copy of this licence, visit http://creativecommons.org/licenses/by/4.0/.

\section{Appendix 1}

\section{See Table 1.}

Table 1 Table Case Study Communities

\begin{tabular}{|c|c|c|c|c|c|c|}
\hline Adult population & $\begin{array}{l}\text { Estevan } \\
\text { Number }\end{array}$ & $\begin{array}{l}\text { Estevan percent } \\
(\%)\end{array}$ & Regina number & $\begin{array}{l}\text { Regina percent } \\
(\%)\end{array}$ & Saskatoon number & $\begin{array}{l}\text { Saskatoon } \\
\text { percent }(\%)\end{array}$ \\
\hline Men & 5660 & 50.2 & 116,885 & 49.4 & 120,640 & 49.0 \\
\hline Women & 5605 & 49.8 & 119,600 & 50.6 & 125,740 & 51.0 \\
\hline Total & 11,265 & 100.0 & 236,485 & 100.0 & 246,376 & 100.0 \\
\hline \multicolumn{7}{|c|}{ Adult population by age group } \\
\hline $15-24$ & 1475 & 16.1 & 29,925 & 15.6 & 33,920 & 16.8 \\
\hline $25-54$ & 4900 & 53.4 & 100,880 & 52.4 & 105,560 & 52.2 \\
\hline $55 \&$ older & 2805 & 30.6 & 61,575 & 32.0 & 62,585 & 31.0 \\
\hline Total & 9180 & 100.0 & 192,380 & 100.0 & 202,065 & 100.0 \\
\hline \multicolumn{7}{|c|}{ Population 15 and older completed education } \\
\hline Grade 12 or less & 3030 & 48.9 & 88,390 & 46.8 & 85,870 & 43.5 \\
\hline Certificate or diploma & 2375 & 38.4 & 66,370 & 35.2 & 74,020 & 37.5 \\
\hline University degree & 785 & 12.7 & 33,910 & 18.0 & 37,345 & 18.9 \\
\hline Total & 6190 & 100.0 & 188,670 & 100.0 & 197,235 & 100.0 \\
\hline \multicolumn{7}{|c|}{ Population 15 and older by gross income } \\
\hline Under $\$ 20,000$ & 1790 & 20.0 & 41,845 & 23.1 & 48,785 & 25.7 \\
\hline 20,000 to 49,999 & 2780 & 31.0 & 61,860 & 34.1 & 67,475 & 35.6 \\
\hline 50,000 plus & 4125 & 46.0 & 77,825 & 42.9 & 73,387 & 38.7 \\
\hline Total & 8965 & 100.0 & 181,530 & 100.0 & 189,647 & 100.0 \\
\hline
\end{tabular}

(Statistics Canada 2017) 


\section{Appendix II}

\section{Focus group questionnaire}

\section{PRE FOCUS GROUP}

Section 1: We would first like to ask you some general questions about the role of energy in Sask.

In Saskatchewan, electricity comes from various different sources including fossil fuels (coal, oil and natural gas), hydro and renewable sources such as wind farms.

Q1 Compared to most people how knowledgeable would you say you are generally about how different types of energy are produced, delivered and used in Saskatchewan?
(a) Strongly agree
(b) Tend to agree
(c) Neither agree nor disagree
(d) Tend to disagree
(e) Strongly disagree
(f) Not Sure/don't Know

Q2 To what extent do you agree or disagree that enough is being done to protect the environment in your local community?
(a) Strongly agree
(b) Tend to agree
(c) Neither agree nor disagree
(d) Tend to disagree
(e) Strongly disagree
(f) Not Sure/don't Know

Q3 Which of the following things do you think are most important when it comes to deciding which types of energy are produced in Saskatchewan?

Please write a "1" next to the one you think is most important, a " 2 " next to the one you think is next most important, and a " 3 " next to the one you think is the least important.

Cost (impact on consumer bills) sources)

Energy independence (not relying on foreign

Effects on the environment (climate change and local air pollution)

\section{Not sure/don't know}

Q4 Using a scale from 1-7 please indicate the extent to which you favor or oppose the uses of these different sources of electricity in Saskatchewan?

\begin{tabular}{lllllllll}
\hline $\begin{array}{l}\text { Energy } \\
\text { source }\end{array}$ & 1 & 2 & 3 & 4 & 5 & 6 & 7 Favor & $\begin{array}{l}\text { Don't } \\
\text { Know }\end{array}$ \\
\hline
\end{tabular}

(a) Solar energy

(b) Wind

energy

(c)

Hydro-

electric

energy

(d) Coal

(e) Natural gas

(f)

Nuclear

energy

(g) Biomass

Q6 There is a lot of talk these days about climate change, that is a long-term change in the planet's weather patterns and average temperatures. People have different views about climate change. Which of these statements best reflects your own views?

(a) Climate change is an immediate and urgent problem

(b) Climate change is more of a problem for the future

(c) Climate change is not really a problem

(d) I' $m$ still not convinced that climate change is happening

(e) Don't know

Q7 Would you say your experience with the development of new infrastructure (transportation, pipelines, waste facilities, etc.) in your community has mainly been positive or negative?

(a) Very positive

(b) Somewhat positive

(c) Neither positive nor negative

(d) Somewhat negative

(e) Very negative

(f) Not sure/don't know

Q8A How important or unimportant do you think it is to the local area that oil and gas continue to be produced in Saskatchewan?

(a) Very important

(b) Fairly important

(c) Neither important nor unimportant

(d) Not very important

(e) Not at all important

(f) Not sure/don't know 
Q8B How important or unimportant do you think it is to the local area that coal continue to be produced in Saskatchewan?
(a) Very important
(b) Fairly important
(c) Neither important nor unimportant
(d) Not very important
(e) Not at all important
(f) Not sure/don't know

Q How much, if anything, would you say you know about carbon capture and storage (CCS)?
(a) Never heard of it before
(b) Heard of it, but don't know what it is
(c) Know a bit about it
(d) Know a lot about it
(e) Don't know

\section{POST FOCUS GROUP}

Section 2: We would now like to ask you about your overall opinion about CCS.

Q Based on what you have heard today, which of the following best describes your overall opinion of the use of carbon capture and storage in Saskatchewan as a whole.
(a) I think it is a very bad idea
(b) I think it is a fairly bad idea
(c) I think there are both good and bad aspects to it
(d) I think is a fairly good idea
(e) I think this is a very good idea
(f) Don't know

Q Please explain the reasons for the opinion you gave in Question 1.

Q Based on what you have heard today, which of the following best describes your overall opinion of the use of carbon capture and storage at Boundary Dam, Estevan.
(a) I think it is a very bad idea
(b) I think it is a fairly bad idea
(c) I think there are both good and bad aspects to it
(d) I think is a fairly good idea
(e) I think this is a very good idea
(f) Don't know

Q Which, if any, of the following would you say is the main benefit of CCS?

(a1) Increased oil recovery from oil fields

(a) Cleaner energy production (b) Less reliance on renewables or nuclear power

(c) More jobs in the region

(d) Other:

(e) There are no major benefits

(f) Don't know

Q And which, if any, of the following would you say is the major drawback of CCS?

(a) Increased prices for electricity

(b) Would prefer to see greater use of renewables

(c) Makes us too reliant on fossil fuels

(d) Risks from $\mathrm{CO} 2$ leaking

(e) Other:

(f) There are no major risks

Q Using a scale from 1-7 please indicate the level to which you believe the CCS Boundary Dam power plant project in Saskatchewan benefited the following:

\begin{tabular}{lllllllll}
\hline $\begin{array}{l}\text { Benefi- } \\
\text { ciary }\end{array}$ & $\begin{array}{l}1 \\
\text { Very } \\
\text { low }\end{array}$ & 2 & 3 & 4 & 5 & 6 & $\begin{array}{l}7 \\
\text { Very } \\
\text { high }\end{array}$ & $\begin{array}{l}\text { Don't } \\
\text { know }\end{array}$ \\
\hline
\end{tabular}
(a) You
and
your
family
(b) Soci-
ety
as a
whole
(c)
Com-
munity
as a
whole

Q To what extent do you agree or disagree that you were given enough information today to form an opinion about CCS?

(a) Strongly agree

(b) Tend to agree

(c) Neither agree nor disagree

(d) Tend to disagree

(e) Strongly disagree

(f) Not sure/don't know

Q To what extent do you feel certain in your overall opinion regarding CCS? I am...

(a) Entirely certain

(b) Mostly certain

(c) Mostly uncertain

(d) Entirely uncertain 


\section{(e) Not sure/don't know}

Q Using a scale from 1-7 please indicate the level to which you believe a proposal to develop a wind project in Saskatchewan would benefit the following:

\begin{tabular}{|c|c|c|c|c|c|c|c|c|}
\hline $\begin{array}{l}\text { Benefi- } \\
\text { ciary }\end{array}$ & $\begin{array}{l}1 \\
\text { Very } \\
\text { low }\end{array}$ & 2 & 3 & 4 & 5 & 6 & $\begin{array}{l}7 \\
\text { Very } \\
\text { high }\end{array}$ & $\begin{array}{l}\text { Don't } \\
\text { know }\end{array}$ \\
\hline
\end{tabular}

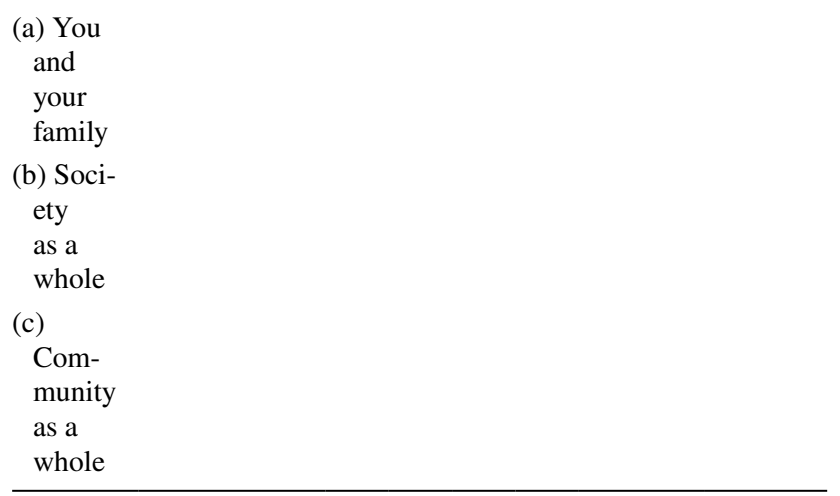

Q Using a scale from 1-7 please indicate the level to which you believe a proposal to develop a wind project in your community would benefit the following:

\begin{tabular}{lllllllll}
\hline $\begin{array}{l}\text { Benefi- } \\
\text { ciary }\end{array}$ & $\begin{array}{l}1 \\
\text { Very } \\
\text { low }\end{array}$ & 2 & 3 & 4 & 5 & 6 & $\begin{array}{l}7 \\
\text { Very } \\
\text { high }\end{array}$ & $\begin{array}{l}\text { Don't } \\
\text { know }\end{array}$ \\
\hline
\end{tabular}
(a) you
and
your
family
(b)
society
as a
whole
(c) com-
munity
as a
whole

Using a scale from 1-7 please indicate the level to which you believe a proposal to develop a nuclear project in Saskatchewan would benefit the following:

\begin{tabular}{lllllllll}
\hline $\begin{array}{l}\text { Benefi- } \\
\text { ciary }\end{array}$ & $\begin{array}{l}1 \\
\text { Very } \\
\text { low }\end{array}$ & 2 & 3 & 4 & 5 & 6 & $\begin{array}{l}7 \\
\text { Very } \\
\text { high }\end{array}$ & $\begin{array}{l}\text { Don't } \\
\text { know }\end{array}$ \\
\hline
\end{tabular}

\section{(a) you \\ and \\ your \\ family}

(b)

society

as a

whole

\begin{tabular}{lllllllll}
\hline $\begin{array}{l}\text { Benefi- } \\
\text { ciary }\end{array}$ & $\begin{array}{l}1 \\
\text { Very } \\
\text { low }\end{array}$ & & & & & & & \\
& & & $\begin{array}{l}\text { Very } \\
\text { high }\end{array}$ & $\begin{array}{l}\text { Don't } \\
\text { know }\end{array}$ \\
\hline $\begin{array}{l}\text { (c) com- } \\
\text { munity } \\
\text { as a } \\
\text { whole }\end{array}$ & & & & & & & & \\
\hline
\end{tabular}

Q Using a scale from 1-7 please indicate the level to which you believe a proposal to develop a nuclear project in your community would benefit the following:

\begin{tabular}{lllllllll}
\hline $\begin{array}{l}\text { Benefi- } \\
\text { ciary }\end{array}$ & $\begin{array}{l}1 \\
\text { Very } \\
\text { low }\end{array}$ & 2 & 3 & 4 & 5 & 6 & $\begin{array}{l}7 \\
\text { Very } \\
\text { high }\end{array}$ & $\begin{array}{l}\text { Don't } \\
\text { know }\end{array}$ \\
\hline
\end{tabular}

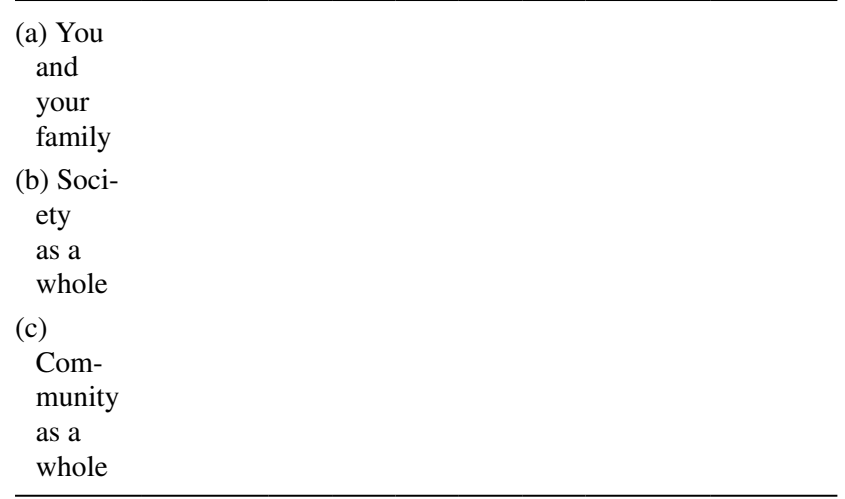

Q To what extent do you think citizens like you can influence government decisions on energy production and use?
(a) To a great extent
(b) To some extent
(c) Hardly at all
(d) Not at all
(e) Don't know

Section 3: In today's group meeting, an expert has provided you with information about energy and CCS. We would like to ask you a couple of questions about this information.

$\mathrm{Q}$ How, if at all, did you did your views change over the course of the discussions?

(a) I became much more negative about CCS

(b) I became slightly more negative about CCS

(c) My views on the subject did not really change

(d) I became much slightly more positive about CCS

(e) I became much more positive about CCS

(f) I did not know about CCS before tonight

(g) Don't know

Q Which of the following best describes how you feel about the information presented? 
(a) I think it was very biased toward.....

(b) I think it was fairly biased against.......

(c) I think it was mostly neutral

(d) Not sure/don't know

Q To what extent did you consider the information provided easy or difficult to understand?
(a) Very easy to understand
(b) Fairly easy to understand
(c) Fairly difficult to understand
(d) Very difficult to understand
(e) Not sure/don't know

Q How much of the information presented was new to you?
(a) All or almost all of it
(b) Some of it
(c) A small amount of it
(d) None of it was new to me
(e) Don't know

Q How useful or otherwise, did you consider the information to be?
(a) Very useful
(b) Fairly useful
(c) Not very useful
(d) Not at all useful
(e) Not sure/don't know

Q How would you rate the expertise of the person who presented the information?
(a) Excellent
(b) Very good
(c) Fairly good
(d) Neither good nor poor
(e) Fairly poor
(f) Very poor
(g) Terrible
(h) Not sure/don't know

0 To what extent do you believe that the person presenting the information in the group meeting was honest?
(a) Very honest
(b) Fairly honest
(c) Neutral
(d) Fairly dishonest
(e) Very dishonest
(f) Not sure/don't know

You have finished the questionnaire. Thank you very much for your participation! Please contact the person in charge of the focus group if you have any further questions.

\section{References}

Allansdottir A, Manzella A, Pellizzone A (2019) Conclusions, in geothermal energy and society. In: Manzella A, Pellizzone A, Allansdottir A (eds) Lecture notes in energy, vol 67. Springer, New York, pp 279-288

Batel S (2018) A critical discussion of research on the social acceptance of renewable energy generation and associated infrastructures and an agenda for the future. J Environ Policy Plan 20(3):356-369. https://doi.org/10.1080/1523908X.2017.1417120

Batel S, Devine-Wright P (2015) Towards a better understanding of people's responses to renewable energy technologies: insights from the Social Representations Theory. Public Underst Sci 24:311-325

Bell D, Gray T, Haggett C (2005) The 'social gap' in wind farm siting decisions: explanations and policy responses. Environ Polit 14(4):460-477

Bell D, Gray T, Haggett C, Swaffield J (2013) Re- visiting the 'social gap': public opinion and relations of power in the local politics of wind energy. Environ Polit 22(1):115-135. https://doi. org/10.1080/09644016.2013.755793

Blue G, Medlock J (2014) Public engagement with climate change as scientific citizenship: a case study of world wide views on global warming. Sci Cult 23(4):560-579. https://doi.org/10.1080/09505 431.2014.917620

Bothello A, Lourenco-Gomes L, Pinto L, Sousa S, Valente M (2017) Accounting for local impacts of photovoltaic farms: the application of two stated preferences approaches to a case-study in Portugal. Energy Policy 109:191-198

Boyd B (2015) Standing committee on crown and central agencies. Hansard Verbatim Report. Legislative Assembly of Saskatchewan. Hansard Verbatim Report No. 27-June 18, 2013, p 7756

Bui M, Adjiman CS, Bardow A, Anthony EJ et al (2018) Carbon capture and storage (CCS): the way forward. Energy Environ Sci 11:1062-1176

Chambers S (2003) Deliberative democratic theory. Annu Rev Polit Sci 6(1):307-326

Delina L, Janetos A (2018) Cosmopolitan, dynamic, and contested energy futures: navigating the pluralities and polarities in the energy systems of tomorrow. Energy Res Soc Sci 35:1-10

Devine-Wright P (2005) Beyond NIMBYism: towards an integrated framework for understanding public perceptions of wind energy. Wind Energy 8:125-139. https://doi.org/10.1002/we.124

Devine-Wright P (2011) Place attachment and public acceptance of renewable energy: a tidal energy case study. J Environ Psychol 31:336-343

Devine-Wright P, Howes Y (2010) Disruption to place attachment and the protection of restorative environments: a wind energy case study. J Environ Psychol. https://doi.org/10.1016/j.jenvp 2010.01.008

Devine-Wright P, Wiersma B (2020) Understanding community acceptance of a potential offshore wind energy project in different locations: an island-based analysis of 'place-technology fit'. Energy Policy 137:111086

Dietz T, Ostrom E, Stern PC (2003) The struggle to govern the commons. Science 302:1907-1912

Djuric M (2019) "Premiers Moe, Ford, Higgs to collaborate on development of nuclear reactors in Canada" Global News Posted December 1, 2019 
Dryzek JS, Pickering J (2017) Deliberation as a catalyst for reflexive environmental governance. Ecol Econ 131:353-360

Elger T (2010) 'Contextualization'. In Mills AJ, Durepos G, Wiebe E (eds) Encyclopedia of Case Study Research, vol 1. Sage Reference Publication, Los Angeles

Estevan, City of (2018) History and Overview. Website. Available at: www.estevan.ca (accessed December 23, 2018)

Geels F (2010) Ontologies, socio-technical transition (to sustainability) and the multi-level perspective. Res Policyt

Hurlbert M (2014) Evaluating public consultation in nuclear energy: the importance of problem structuring and scale. Int J Energy Sect Manag 8(1):56-75

IEA (2016) Energy, Climate Change \& Environment. 2016 Insights. Available at: http://www.iea.org/publications/freepublications/ publication/ECCE2016.pdf

IEA (2018) International Energy Agency at COP24

IPCC (2019) Climate Change and Land Report. Available at: ipcc. $\mathrm{ch} / \mathrm{srccl} /$

Kaarbo K, Beasley RK (1999) A practical guide to the comparative case study method in political psychology. Psychology 20(2):369-391

Kahneman D (2011) Thinking, fast and slow. Farrar, Straus and Giroux, New York

Koelbl et al (2014) Uncertainty in Carbon Capture and Storage (CCS) deployment projections: a cross-model comparison exercise. Clim Change 123:461-476

Lehmann P, Creutzig F, Ehlers MH, Friedrichsen N, Heuson C, Hirth L, Pietzcker R (2012) Carbon lock-out: advancing renewable energy policy in Europe. Energies 5:323-354

Mann C, Voß J, Amelung N, et al (2014) Challenging futures of citizen panels. Critical issues for robust forms of public participation. A report based on interactive anticipatory assessment of the dynamics of governance instruments. Technische Universität Berlin, Berlin

MIT (2018) The future of nuclear energy in a carbon-constrained world. An Interdisciplinary MIT Study. MIT Future of Energy Initiative. Massachusetts Institute of Technology, Massachusetts

Moezzi M, Janda KB, Rotmann S (2017) Using stories, narratives, and storytelling in energy and climate change research. Energy Res Soc Sci 31:1-10

Osazuwa Peters O, Hurlbert M, McNutt K, Rayner J, Gamtess S (2020) Saskatchewan's energy future: risk and pathways analysis. Environ Innov Soc Trans 34:237-250

Ostfeld, R, Reiner DM (2020) Public views of Scotland's path to decarbonization: evidence from citizens' juries and focus groups. Energ Policy 140:111332

Owen R, Macnaghten P, Stilgoe J (2012) Responsible research and innovation: from science in society to science for society, with society. Sci Public Policy 39:751-760

Parker R (2009) How Saskatoon Got the Nickname POW. Retrieved 23 Dec 2018

Pellizzone Al, Allandsdottir A, De Franco R, Muttoni G, Manzella A (2017) Geothermal energy and the public: a case study on deliberative citizens' engagement in central Italy. Energy Policy 101:561-570

Pellizzone A, Manzella A, Allansdottir A (2019) European geothermal congress. Den Haag, The Netherlands, 11-14 June 2019

Pidgeon N, Demski C, Butler C, Parkhill K, Spence A (2014) Creating a national citizen engagement process for energy policy. Proc Natl Acad Sci USA 111:13606-13613
Regina (2018) City of Regina. Available at: Regina.ca. Accessed 21 Dec 2018

Rittel HWJ, Webber MM (1973) Wicked problems. Policy Sci 4(2):155-169

Saskatoon (2017) Found locally. Available at: saskatoon.foundlocally. com. Accessed 21 Dec 2018

Saskatoon (2018) City of Saskatoon. Available at: Saskatoon.ca. (Accessed December 21, 2018)

SaskPower (2019) SaskPower 2018-2019 Annual Report. Regina, Saskatchewan. Accessed 14 Oct 2019

Shaw C, Corner A (2017) Using Narrative Workshops to socialise the climate debate: Lessons from two case studies - centre-right audiences and the Scottish public 31:273-283

Sovacool B (2014) What are we doing here? Analyzing fifteen years of energy scholarship and proposing a social science research agenda. Energy Res Soc Sci 1:1-29

Sovacool B, Ryan K, Stern E et al (2015) Integrating social science in energy research. Energy Res Soc Sci 6:95-99

Statistics Canada (2017) Census Profile. 2016 Census. Canada Catalogue no. 98-316-X2016001. Ottawa. Released September 13, 2017. http://www12.statcan.gc.ca/census-recensement/2016/ dp-pd/prof/index.cfm?Lang $=\mathrm{E}$

Sundqvist R (2004) What causes the disparity of electricity externality estimates? Energy Policy 32:1753-1766

Tavoni et al (2012) The value of technology and of its evolution towards a low carbon economy. Clim Change 114:39-57

Tokar B (2015) Democracy, localism, and the future of the climate movement. World Futures 71(3-4):65-75. https://doi. org/10.1080/02604027.2015.1092785

Urcan SA, Dryzek J (2015) The reach of deliberative democracy. Policy Stud 36(3):241-248. https://doi.org/10.1080/01442 872.2015.1065969

Urquiza A, Amigo C, Billi M, Espinosa P (2018) Participatory energy transitions as boundary objects: the Case of Chile's Energia2050. Front Energy Res. https://doi.org/10.3389/fenrg.2018.00134

Van Vliet et al (2014) The impact of technology availability on the timing and costs of emission reductions for achieving long-term climate targets. Clim Change 559-569

Vaughan NE, Lenton TM (2011) A review of climate geoengineering proposals. Clim Change 109(3):745-790. https://doi.org/10.1007/ s10584-011-0027-7

Vob J-P, Amelung N (2016) Innovating public participation methods: Technoscientization and reflexive engagement. 46(5):749-772

Walker G (1995) Energy, land use and renewables. A changing agenda. Land Use Policy 12(1):3-6

Wustenhagen R, Wolsink M, Burer MJ (2007) Social acceptance of renewable energy innovation: an introduction to the concept. Energy Policy 35:2683-2691

Yin RK (2014) Case study research: designs and methods, 5th edn. SAGE Publications Inc, Los Angeles

Publisher's Note Springer Nature remains neutral with regard to jurisdictional claims in published maps and institutional affiliations. 